\title{
Pemetaan Informasi Sebaran Bidang Ilmu Pada Skripsi Fakultas \\ Ekonomi dan Manajemen Lulusan IPB University Tahun 2015-2019 Berdasarkan Standar Universal Decimal Classification: Suatu Kajian Bibliometrika
}

\author{
Ratnaningsih ${ }^{1}$ dan Lindawati ${ }^{2}$ \\ Perpustakaan IPB University

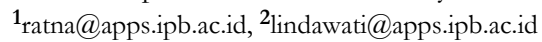

\begin{abstract}
Abstrak
Pendahuluan. Sektor ekonomi memegang peranan penting bagi Indonesia sebagai negara berkembang, pemerintah telah mengupayakan berbagai program untuk meningkatkan pendapatan per kapitanya dengan menumbuhkan berbagai sektor, khususnya menyoroti porsi ekspor nasional yang masih rendah terhadap Produk Domestik Bruto (PDB) yakti sebesar 25 persen. Keberadaan Fakultas Ekonomi dan Manajemen (FEM) di Institut Pertanian Bogor tentunya akan memberikan masukan kepada pemerintah melalui penelitian dan pengembangan yang dilaksanakan oleh dosen/peneliti dan mahasiswa (program sarjana, pasca sarjana dan program doktor). Untuk mengetahui dan memotret penelitian yang dilakukan oleh mahasiswa program sarjana maka penelitian ini dilakukan
\end{abstract}

Metode dan Pengumpulan Data. Sampel dibatasi hanya pada skripsi 5 tahun terakhir (2015-2019) yang diambil dari repositori IPB.

Analisis Data. Pemetaan dilakukan berdasar pada Klasifikasi UDC. Tabel skripsi dianalisis secara deksriptif dan dipetakan mengounakan VosViewer.

Hasil dan Pembahasan. Jumlah penelitian skripsi Fakultas Ekonomi dan Manajemen IPB selama 2015-2019 adalah 3.145 judul. Topik paling banyak diteliti adalah "Situasi ekonomi, kebijakan ekonomi, manajemen ekonomi, perencanaan ekonomi. Produksi, jasa dan harga" dengan jumlah penelitian sebanyak 926 judul penelitian, sedangkan yang paling sedikit adalah topik terkait "Asuransi” dengan jumlah penelitian sebanyak 6 judul penelitian.

Kata kunci yang memiliki keterhubungan paling banyak adalah "pemasaran" dengan jumlah keterhubungan sebanyak 204 hubungan. Analisis kata kunci menggunakan VosV Viewer terbagi menjadi 16 kluster dengan kluster terbesar yaitu kluster 1 terdiri dari 69 kata kunci dan kluster terkecil kluster 12 terdiri dari 3 kata kunci. Selanjutnya dosen pembimbing utama yang paling produktif membimbing mahasiswa adalah Jono Mintarto Munandar (126 bimbingan).

Kesimpulan. Topik paling diminati adalah "Situasi ekonomi, kebijakan ekonomi, manajemen ekonomi, perencanaan ekonomi. Produksi, jasa dan harga" ( 926 judul). Kata kunci paling banyak adalah "pemasaran" dengan kemunculan sebanyak 205 kali. Dosen pembimbing utama paling produktif adalah Jono Mintarto Munandar dengan jumlah bimbingan sebanyak 126 mahasiswa.

Kata kunci: Ekonomi, Manajemen, Kebijakan ekonomi, skripsi mahasiswa, tugas akhir program sarjana, Bibliometrik.

\begin{abstract}
Introduction. The economic sector plays an important role for Indonesia as a developing country, the government has sought various programs to increase its per capita income by growing various sectors, particularly highlighting the still low portion of national exports of Gross Domestic Product (GDP) of 25 percent. The existence of the Faculty of Economics and Management (FEM) at the Bogor Agricultural Institute will certainly provide input to the government through research and development carried out by lecturers/researchers and students (undergraduate, postgraduate and doctoral programs). To find out and photograph the research carried out by undergraduate students, this research was carried out

Methods and Data Collection. The sample is limited to the thesis of the last 5 years (2015-2019) which is taken from the IPB repository.

Data analysis. Mapping is reviewed based on the UDC Classification. The table was analyzed descriptively and mapped using VosViewer.

Results and Discussion. The number of thesis researches of the Faculty of Economics and Management of IPB during 2015-2019 is 3,145 titles. The most researched topics are "Economic situation, economic policy, economic management, economic planning. Production, services and prices" with a total of 926 research titles, while the least is a topic related to "Insurance" with a total of 6 research titles.
\end{abstract}


The keyword that has the most connectedness is "marketing" with a total of 204 relationships. Keyword analysis using VosViewer is divided into 16 clusters with the largest cluster, namely cluster 1 consisting of 69 keywords and the smallest cluster cluster 12 consisting of 3 keywords. Furthermore, the main supervisor who is most productive in guiding students is Jono Mintarto Munandar (126 guidance).

Conclusion. The most popular topics are "Economic situation, economic policy, economic management, economic planning. Production, services and prices" (926 titles). The most common keyword is "marketing" with 205 occurrences. The most productive main supervisor is Jono Mintarto Munandar with a total of 126 students.

Keywords: Economics, Management, Economic policy, student thesis, undergraduate final project, Bibliometric.

\section{PENDAHULUAN}

\section{Latar Belakang}

Indonesia saat ini masih di kategorikan negara berkembang, kondisi tersebut mengacu kepada klasifikasi Bank Dunia. Kriteria pertama negara maju adalah pendapatan nasional bruto berada di atas 12.000 dollar AS per kapita. Angka tersebut masih sangat jauh dari Indonesia. Sementara pendapatan per kapita nasional masih sebesar 3.840 dollar AS, sehingga World Bank masih mengkategorikan sebagai negara berpendapatan menengah ke bawah. (Romly, 2020) Kondisi tersebut memacu Indonesia untuk lebih meningkatkan pendapatan per kapitanya dengan menumbuhkan berbagai sektor, khususnya menyoroti porsi ekspor nasional yang masih rendah terhadap Produk Domestik Bruto (PDB) yakni sebesar 25 persen.

Untuk meningkatkan pendapatan per kapita negara tersebut, Menteri Koordinator (Menko) Perekonomian Airlangga Hartarto telah mencanangkan Program Prioritas Nasional Bidang Perekonomian. Pertama, Membangun sumber daya manusia (SDM) yang dapat menjadi pekerja keras. dinamis, terampil, menguasai ilmu pengetahuan dan teknologi, serta bekerja sama dengan talenta global. Kedua, menyangkut infrastruktur yang terkait langsung dengan pemda yaitu Kebijakan Satu Peta. Program percepatan kebijakan satu peta merupakan program perbaikan data spasial, yang mengacu pada satu standar, satu referensi, satu basis data dan satu geoportal. Ketiga, penyederhanaan regulasi melalui penerbitan dua omnibus law dengan dukungan program Omnibus Law Cipta Lapangan Kerja dan Omnibus Law Perpajakan. Keempat, penyederhanaan birokrasi melalui reformasi birokrasi dan otomasi dan integrasi sistem layanan dengan dukungan program berupa Ekosistem Kemudahan Berusaha, elektronifikasi Keuangan Daerah dan Sistem OSS. Kelima, berkaitan dengan transformasi ekonomi. Indonesia akan melepas ketergantungan terhadap sumber daya alam (SDA) menjadi daya saing manufaktur dan jasa modern yang mempunyai nilai tambah tinggi. (Paath, 2019)

Dalam mendukung program yang dicanangkan di bidang perekonomian, pemerintah dalam hal ini Presiden RI (Joko Widodo) telah menerbitkan UU No. 24 tahun 2019 tentang Ekonomi Kreatif yang bertujuan untuk mengoptimalkan kreatifitas sumber daya manusia yang berbasis warisan budaya, ilmu pengetahuan, dan atau teknologi. Pengelolaan Ekonomi Kreatif dan potensinya perlu dilakukan secara sistematis, terstruktur, dan berkelanjutan. Melalui pengembangan Ekosistem Ekonomi Kreatif yang memberikan nilai tambah pada produk Ekonomi Kreatif yang berdaya saing tinggi, mudah diakses, dan terlindungi secara hukum. Sebagaimana pasal 33 ayat (4) UndangUndang Negara Republik Indonesia Tahun 1945. Untuk mendukung program yang dicanangkan dan ditetapkan pemerintah, tentunya peran serta masyarakat Indonesia sangat berpengaruh khususnya masyarakat akademik. Sesuai pasal 11 ayat 2, UU No. 24 tahun 2019, pengembangan Ekosistem Ekonomi Kreatif yang dapat dilakukan masyarakat akademik melalui pengembangan perguruan tinggi adalah (a) pengembangan riset (b) pengembangan pendidikan. (Kementrian Sekretariat Negara RI, 2019)

Institut Pertanian Bogor sebagai salah satu perguruan tinggi terkemuka di Indonesi, mempunyai peran dan tanggung jawab dalam mendukung program pemerintah di bidang perekonomian sesuai undang-undang yang telah 
ditetapkan melalui Ekonomi Kreatif. Keberadaan Fakultas Ekonomi dan Manajemen (FEM) di Institut Pertanian Bogor tentunya akan memberikan masukan kepada pemerintah melalui penelitian dan pengembangan yang dilaksanakan oleh dosen/peneliti dan mahasiswa (program sarjana, pasca sarjana dan program doktor). Fakultas Ekonomi dan Manajemen IPB mempunyai Visi untuk menjadi pusat keunggulan dalam pendidikan, penelitian dan layanan publik di bidang ekonomi dan manajemen, dengan sudut pandang holistik, pendekatann analitis kuantitatif dan kualitatif yang kuat dan orientasi menuju pembangunan berkelanjutan untuk peningkatan kesejahteraan manusia. (Institut Pertanian Bogor, 2017) Untuk mengetahui sejauh mana penelitian yang sudah dilakukan di IPB, khususnya yang dilakukan oleh mahasiswa program sarjana, di bidang ekonomi manajemen di IPB maka perlu dilakukan kajian pemetaan hasil-hasil penelitian tersebut.

Ruang lingkup penelitian dibatasi pada data tugas akhir atau skripsi yang ditulis oleh mahasiswa program sarjana atau strata 1 (S1) di Fakultas Ekonomi dan Manajemen IPB, di mana skripsi tersebut merupakan salah satu syarat dalam menyelesaikan studinya di IPB. Tahun skripsi dibatasi hanya dari tahun kelulusan 2015 sampai dengan tahun kelulusan 2019, atau selama 5 tahun..

Penelitian ini bertujuan untuk:

1. Mengetahui sebaran topik penelitian bidang ekonomi dan manajemen pada tugas akhir (skripsi) mahasiswa program sarjana atau strata 1 (S1) Fakultas Ekonomi dan Manajemen, Institut Pertanian Bogor.

2. Membuat peta bidang ilmu pada penelitian mahasiswa program sarjana atau strata 1 (S1) pada Fakultas Ekonomi dan Manajemen IPB berdasarkan kelompok bidang ilmu dalam standar Universal Decimal Classification.

3. Mengetahui produktivitas dosen Fakultas Ekonomi dan Manajemen IPB dalam membimbing skripsi mahasiswa S1 selama 5 tahun terakhir (2015 - 2019).

4. Menampilkan peta jalan (road map) penelitian mahasiswa tingkat sarjana di Fakultas Ekonomi dan Manajemen IPB dan merupakan bagian dari peta jalan (road map) penelitian mahasiswa tingkat sarjana di Institut Pertanian Bogor selama 5 tahun terakhir.

\section{KAJIAN PUSTAKA}

Ilmu Pengetahuan adalah suatu sistem berbagai pengetahuan yang didapatkan dari hasil pemeriksaan yang dilakukan secara teliti dengan menggunakan suatu metode tertentu. Jadi, ilmu adalah segala proses kegiatan terhadap suatu keadaan dengan menggunakan alat, prosedur, cara, metode, sehingga menghasilkan pengetahuan baru bagi manusia itu sendiri (Wikipedia, 2017). Saat ini ilmu pengetahuan dan teknologi berkembang dengan cepat, penguasaan ilmu pengetahuan perlu di miliki dan dikuasai oleh setiap manusia baik melalui pendidikan formal maupun informal. Pendidikan formal biasanya dimulai dari jenjang pendidikan dasar, menengah dan pendidikan tinggi. Jenjang Pendidikan tinggi (perguruan tinggi) adalah jenjang tertinggi dalam tingkatan pendidikan yang terdiri dari strata-1, strata-2 dan strata-3. Setiap jenjang di perguruan tinggi menghasilkan karya ilmiah yang merupakan tugas akhir dari mahasiswa. Karya ilmiah yang dihasilkan oleh mahasiswa harus mengikuti tata cara pedoman penulisan yang telah ditetapkan oleh perguruan tinggi. Setiap mahasiswa dalam menempuh program strata 1 (S-1), diwajibkan mengikuti perkuliahan dengan menyelesaikan kurang lebih 135 SKS yang ditempuh selama 8 semester. Penulisan skripsi biasanya di selesaikan pada akhir semester dengan bimbingan dosen sesuai bidang ilmunya. Pengertian skripsi menurut (Darmono \& Hasan, 2002) adalah

"Skripsi merupakan karya ilmiah yang ditulis oleb mahasiswa program sarjana pada akbir masa studinya berdasarkan hasil penelitian atau kajian

kepustakaan, atau pengembangan terhadap suatu masalah yang dilakukan secara seksama."

Menurut Pedoman penulisan karya ilmiah IPB bahwa "Skripsi adalah tugas akhir bagi mahasiswa jenjang S-1 yang bertujan mengenalkan dan melath mahasiswa menerapkan ilmu pengetahuan dan teknologi serta memecahkan masalah yang ditemui di lapangan". Dengan demikian skripsi merupakan 
syarat yang harus di penuhi oleh mahasiswa dalam menyelesaikan pendidikannya di program strata-1.

Sistem klasifikasi Universal Decimal Classification (UDC) adalah sistem klasifikasi bahan perpustakaan yang dikembangkan oleh pakar bibliografi Belgia, Paul Otlet dan Henri la Fontaine pada akhir abad ke-19. Bagan klasifikasi ini dikembangkan berdasarkan bagan klasifikasi Dewey Decimal Classification (DDC), tetapi menggunakan tambahan simbol-simbol untuk mengindikasikan berbagai aspek dari subyek dan hubungan antar subyek. Oleh karenanya bagan tersebut mengandung elemen faset dan analisissintetik. Bagan klasifikasi ini kebanyakan digunakan perpustakaan khusus karena dapat membuat subyek yang spesifik. UDC terus dimodifikasi dan diperluas selama beberapa tahun untuk menyesuaikan diri dengan pertumbuhan ilmu pengetahuan dan secara terus menerus dikembangkan untuk menyesuaikan dengan perkembangan. UDC dapat digunakan untuk mengklasifikasi berbagai bentuk media dan tidak terbatas pada buku atau media tercetak saja, tetapi juga dapat digunakan untuk mengklafikasi film, video, rekaman suara, peta, jurnal dan koleksi museum. Sistem klafikasi UDC didasarkan pada sistem desimal dan membagi ilmu pengetahuan ke dalam sepuluh kelompok utama. Untuk memudahkan membaca, angka dalam UDC biasanya diberi titik setelah 3 digit. Misalnya angka 61 adalah Ilmu Kedokteran, kemudian subdivisi dibawahnya adalah 611 Anatomi. Subdivisi di bawah anatomi kemudian diberi titik sebelumnya seperti 611.1, 611.2 dan seterusnya. Pada bagan/table utama didaftar sepuluh kelas ilmu pengetahuan. Masing-masing kelas tersebut kemudian dibagi ke dalam sepuluh bagian lagi. Adapun kelas utama dari UDC adalah sebagai berikut: (0) Sain dan Pengetahuan. Organisasi. Ilmu Komputer. Ilmu Informasi. Dokumentasi. Kepustakawanan. Lembaga. Publikasi, (1) Filsafat. Psikologi, (2) Agama. Teologi, (3) Ilmu sosial, (4) Kosong, (5) Matematika.llmu Pengetahuan Alam, (6) Ilmu Terapan. Kedokteran. Teknologi (7) Seni. Olah Raga, (8) Linguistik. Literatur, (9) Geografi. Sejarah (Concortium, 2019).
Cabang ilmu ekonomi dan manajemen sebagian besar termasuk kelompok ilmu sosial yang meliputi klas 330 yaitu dengan subyek Economics. Bidang yang dikaji pada penelitian ini yaitu (1) Ilmu Ekonomi (2) Manajemen (3) Agribisnis (4) Ekonomi dan Sumberdaya Lingkungan, dan (5) Ekonomi Syariah. Masing masing subyek besar ini akan dibagi lagi dengan subyek yang lebih spesifik sesuai standar Universal Decimal Classification.

Penelitian terkait pemetaan yang dilakukan pada tahun 2019 oleh Saleh dan Himawan dengan judul "Pemetaan Informasi Sebaran Bidang Ilmu pada Penelitian Skripsi Fakultas Perikanan dan Ilmu Kelautan IPB Lulusan Tahun 2014-2018 Berdasarkan Standar Universal Decimal Classification"' (Saleh \& Himawan, 2019). Penelitian ini menyimpulkan antara lain: (1) Bidang yang menjadi penelitian mahasiswa FPIK terdiri dari dua kelompok besar yaitu bidang yang terkait komoditas perikanan (sebanyak 546 judul atau 29,90\%) dan bidang non-komoditas perikanan (sebanyak 1280 judul atau 70,10\%); (2) Penelitian terkait komoditas perikanan terdiri dari mengenai komoditas ikan (sebanyak 347 penelitian atau 63,55\%) dan komoditas non-ikan (sebanyak 199 penelitian atau 36,45\%); (3) Ikan lele merupakan jenis ikan yang terbanyak menjadi obyek penelitian pada kelompok penelitian tentang ikan air tawar yaitu sebanyak 64 penelitian, sedangkan ikan baung, lelawak, uceng, dan tambakan merupakan jenis ikan yang paling sedikit diteliti yaitu masing-masing hanya 1 penelitian. Sedangkan pada jenis ikan laut/payau, ikan sidat merupakan ikan yang paling banyak diteliti (21 penelitian). Ikan baronang dan swanggi merupakan ikan yang paling sedikit diteliti. Bahkan banyak ikan-ikan endemik Indonesia yang belum dijadikan obyek penelitian; (3) Dosen paling produktif membimbing adalah Agoes Mardiono Jacoeb dengan jumlah bimbingan sebanyak 81 mahasiswa. Jumlah ini terbagi menjadi sebagai pembimbing utama 24 mahasiswa bimbingan, dan sebagai pembimbing anggota sebanyak 57 mahasiswa bimbingan.

Penelitian kedua adalah penelitian yang dilakukan oleh Ratnaningsih dan Aat Atnah dengan judul Pemetaan Bidang Ilmu Pada Skripsi Fakultas Ekologi Manusia Lulusan Tahun 2014 
2018 Berdasarkan Standar Universal Decimal Classification (Ratnaningsih \& Atnah, 2019). Penelitian ini menyimpulkan bahwa: (1) Jumlah penelitian skripsi mahasiswa Fakultas Ekologi Manusia IPB selama lima tahun terakhir (20142018) berjumlah 1.814 judul penelitian. Jumlah tersebut terdiri atas skripsi mahasiswa Departemen Gizi Masyarakat sebanyak 764 judul penelitian (42\%), kemudian Departemen Sains Komunikasi dan Pengembangan Masyarakat sebanyak 677 judul penelitian (37\%), dan yang terakhir adalah Departemen Ilmu Keluarga dan Konsumen sebanyak 373 judul penelitian (21\%); (2) Hasil penelitian mahasiswa Strata 1 Fakultas Ekologi Manusia yang tertinggi di Departemen Gizi Masyarakat yang banyak di teliti adalah Konsumsi Pangan (223 judul); Status Gizi (147 judul) dan Pengetahuan Gizi (150 judul). Untuk bidang lainnya, dapat dijadikan peluang untuk dijadikan bidang penelitian; (3) Dosen pembimbing yang paling produktif membimbing mahasiswa selama kurun waktu 2014-2018 adalah M Rizal Martua Damanik sebanyak 54 bimbingan mahasiswa.

Penelitian ketiga dilakukan oleh Sri Rahayu dan Saleh dengan judul "Studi Bibliometrik dan Sebaran Topik Penelitian Pada Jurnal Hayati Terbitan 2012-2016" (Rahayu \& Saleh, 2017). Kesimpulan pada kajian ini adalah sebagai berikut: (1) Artikel yang dimuat pada Jurnal Hayati meliputi cabang ilmu biodiversity, biosystematics, ecology, physiology, behavior, genetics, dan biotecbnology. Pada kajian ini cabang ilmu dari artikel yang paling banyak dimuat adalah physiology yaitu sebanyak 46 artikel (30,07\%), sedangkan yang artikel dari cabang ilmu biosystematics dan behavior tidak banyak dimuat yaitu masing-masing hanya sebanyak 8 artikel (5,23\%); (2) Dari 153 artikel yang dimuat dalam Jurnal Hayati volume 19 sampai dengan 23 melibatkan 570 nama penulis. Penulis paling produktif adalah Bambang Suryobroto dengan 7 artikel, kemudian posisi kedua ditempati oleh Antonius Suwanto dan Iman Rusmana masing-masing dengan 6 artikel, dan posisi ketiga oleh Muhammad Sadikin dengan 5 artikel; (3) Derajat atau tingkat kolaborasi kepenulisan pada Jurnal Hayati adalah sebesar 0,94. Derajat kolaborasi kepenulisan tersebut cukup tinggi khususnya pada terbitan tahun 2014 dan terbitan tahun 2016 yang nilainya mencapai satu. Artinya pada dua tahun tersebut semua artikel ditulis oleh penulis ganda; (4) Indeks kolaborasi penulis Pada Jurnal Hayati rata-rata adalah sebesar 3,72. Indeks tertinggi adalah pada terbitan tahun 2014 yaitu sebesar 4,08 dan indeks kolaborasi penulis paling rendah adalah sebesar 3,55 yaitu pada tahun 2015; (5) Pustaka yang paling banyak digunakan sebagai referensi dalam artikel pada Jurnal Hayati adalah artikel jurnal yaitu rata-rata sebanyak 26,05 judul per artikel $(88,92 \%)$, sedangkan yang berasal dari buku ratarata sebanyak 1,99 judul per artikel (6,79\%). Sebagian besar referensi tersebut berbahasa asing (Inggris) yaitu sebesar 93,39\% dan yang berbahasa Indonesia sebesar 6,61\%; (6) Rata-rata jumlah sitiran pada Jurnal Hayati adalah sebesar 29, 27 \% sitiran per artikel. Sitiran yang digunakan umumnya berumur 6-10 tahun (30,70\%). Derajat atau tingkat keusangan (obsolescence) referensi yang digunakan penulis pada Jurnal Hayati adalah 6,9 tahun.

Penelitian keempat dilakukan oleh Deden Himawan dan Ratnaningsih dengan judul Penelitian Peningkatan Layanan Data dan Informasi dalam Rangka Memenuhi Kebutuhan Informasi di Perpustakaan Perguruan Tinggi: suatu kajian deskriptif analisis terhadap 5 bunga komersial utama dan 7 bunga potensial komersial (Ratnaningsih \& Himawan, 2016). Kajian ini menyimpulkan bahwa: (1) Penelitian belum dilakukan secara merata terhadap masing-masing jenis dari 5 jenis bunga komersial dan 7 bunga potensial komersial karena belum adanya penelitian terkait beberapa bunga jenis tertentu; (2) Anggrek merupakan jenis bunga yang paling banyak diteliti oleh mahasiswa program sarjana (skripsi), pascasarjana (tesis), maupun doktor (disertasi); (3) Bidang yang paling banyak dikaji adalah bidang budidaya pertanian. Untuk bidang lainnya, dapat dijadikan peluang untuk dijadikan bidang penelitian; (4) Peta/road map terkait 5 bunga komersial dan 7 bunga potensial komersial merupakan salah satu bentuk produk perpustakaan dalam layanan data dan informasi kepada pengguna khususnya kelompok pimpinan; (5) Peta/road map terkait 5 bunga komersial dan 7 bunga potensial komersial dapat menjadi masukan kepada kelompok pimpinan 
dalam pengambilan keputusan maupun kebijakan dalam mendukung pengembangan bunga nusantara.

\section{METODE PENELITIAN}

Penelitian ini merupakan penelitian kombinasi antara kualitatif dan kuantitatif (mixed methods). Digunakan metode kombinasi karena peneliti ingin memperoleh data dan informasi yang lengkap, valid, reliable, dan obyektif. Penelitian kualitatif sendiri merupakan penelitian tentang riset yang bersifat deskriptif dan cenderung menggunakan analisis. Proses dan makna (perspektif subjek) lebih ditonjolkan dalam penelitian kualitatif. Sedangkan penelitian kuantitatif merupakan penelitian ilmiah yang sistematis terhadap bagian-bagian dan fenomena serta hubunganhubungannya. Tujuan penelitian kuantitatif adalah mengembangkan dan menggunakan model-model matematis, teori-teori dan/atau hipotesis yang berkaitan dengan fenomena alam (Sugiyono, 2014). Terhadap hasil pengamatan dan wawancara dilakukan analisis deskriptif di mana analisis deskriptif diartikan sebagai analisis yang dilakukan untuk menilai karakteristik dari sebuah data (Hidayat, 2012). Analisis deskriptif menurut Sugiyono adalah suatu metode yang berfungsi untuk mendeskripsikan atau memberi gambaran terhadap obyek yang diteliti melalui data atau sampel yang telah terkumpul sebagaimana adanya tanpa melakukan analisis dan membuat kesimpulan yang berlaku untuk umum (Sugiyono, 2014).

\section{Data dan Teknik Sampel}

Penelitian ini memilih seluruh skipsi lulusan Fakultas Ekonomi dan Manajemen dari lulusan tahun 2015 sampai 2019 sebagai populasi dari objek penelitian. Penarikan sampel menggunakan metode purposive sampling dengan batasan tahun 2015 sampai tahun 2019 sebanyak 3151 skripsi. Teknik penarikan sampel purposive sampling adalah salah satu teknik sampling non random sampling di mana peneliti menentukan pengambilan sampel berdasarkan pertimbangan tertentu dari peneliti sesuai dengan maksud dan tujuan penelitian, serta terutama bahwa sampel itu memang akan mempunyai data yang diinginkan oleh peneliti untuk keberhasilan penelitiannya (Muljono, Sujana, \& Prabowo, 2009)

Data skripsi yang digunakan dalam penelitian ini didapatkan dari basis data skripsi yang dimiliki oleh Pepustakaan IPB. Kriteria data yang diambil, yaitu data 5 (lima) tahun terakhir (tahun 2015 sampai tahun 2019). Data ditarik dengan simbol Fakultas Ekonomi dan Manajemen IPB, sesuai standar yang berlaku. Selanjutnya, data ditabulasi sesuai dengan kelompok departemen di Fakultas Ekonomi dan Manajemen yang terdiri dari Ilmu Ekonomi, Manajemen, Agribisnis, Ekonomi dan Sumberdaya Lingkungan, serta Ekonomi Syariah. Setelah tabulasi, data dikelompokkan berdasarkan bidang ilmu sesuai dengan standar Universal Decimal Classification. Hasil pengelompokan akan menghasilkan tabel yang selanjutnya dianalisis dengan analisis deskriptif.

Penelitian ini menggunakan wawancara dengan informan dan narasumber sesuai dengan kriteria yang dibutuhkan penelitian ini. Kriteria tersebut adalah infoman atau narasumber yang memiliki kewenangan untuk mengambil kebujakan dalam penelitian tugas akhir, diantaranya Ketua Departemen, Kepala Laboratorium, dan Pimpinan Fakultas (Dekan dan Wakil Dekan). Informan yang dibutuhkan dalam wawancara ini adalah 1-5 informan yang akan diwawancara bergilir hingga memperoleh cukup informasi. Wawancara dilakukan secara tidak terstruktur dan wawancara dilakukan berdasarkan panduan wawancara. Penelitian ini menggunakan non-probability sampling sebagai teknik sampling. Teknik sampling tersebut adalah teknik yang tidak memberikan peluang/kesempatan menjadi sampel yang sama untuk semua unsur populasi (Sugiyono, 2014). Pemilihan naasumber pada penelitian ini menggunakan teknik snowball sampling yang pemilihan informan akan bedasarkan informasi yang didapatkan dari informan sebelumnya atau informan lain dalam penelitian ini. Pencarian informan akan behenti saat infomasi yang didapatkan sudah mencukupi. Metode pengambilan sampel seperti ini dilakukan jika menghadapi populasi di mana data mengenai anggota populasi tidak diketahui dan hanya satu atau beberapa anggota populasi saja yang 
diketahui Invalid source specified. (Muljono, Sujana, \& Prabowo, 2009)

\section{Pengolahan Data}

Data dari sampel basis data skripsi dan informasi dari hasil wawancara akan diolah dengan cara ditabulasi, kemudian tabulasi dianalisis secara deskriptif kualitatif. Analisis data adalah proses mencari dan menyusun secara sistematis data yang diperoleh dari data dan hasil observasi, wawancara, catatan lapangan, dan dokumentasi, dengan cara mengorganisasikan data ke dalam kategori, menjabarkan ke dalam unit-unit, melakukan sintesis, menyusun ke dalam pola, memilih mana yang penting dan yang akan dipelajari, dan membuat kesimpulan sehingga mudah dipahami oleh diri sendiri maupun orang lain (Sugiyono, 2014). Khusus untuk data kualitatif dilakukan menggunakan metode analisis maju bertahap menurut Spradley (1980) sebagaimana dikutip oleh Muljono dkk di mana analisis data dilakukan bersamaan dengan pengumpulan data, artinya ketika dilakukan observasi saat itu pula dilakukan wawancara tahap tersebut. Hasil observasi dan wawancara tersebut kemudian dianalisis dan hasilnya digunakan untuk melakukan observasi dan wawancara tahap berikutnya (Muljono, Sujana, \& Prabowo, 2009). Aplikasi VosViewer yang dikembangkan oleh Nees Jan van Eck and Ludo Waltman digunakan untuk menyajikan peta kata kunci atau co-word dan kepadatan kata kunci (density visualization) yang muncul dalam dokumen skripsi Fakultas Teknologi Pertanian IPB tahun 20152019. Aplikasi VosViewer merupakan program aplikasi komputer yang dapat digunakan untuk melihat peta bibliometrik (Tupan, 2016). Sedangkan menurut Purwoko aplikasi VosViewer salah satunya digunakan untuk memvisualkan bibliografi, atau data set yang berisi field bibliografi dan dalam penelitian, aplikasi ini digunakan untuk analisis bibliometrik serta mencari topik yang masih memiliki peluang untuk diteliti (Purwoko, 2020). Untuk mendapatkan peta co-word atau kata kunci pada penelitian mahasiswa, kajian ini menelusuri kata kunci yang digunakan oleh mahasiswa pada saat melakukan unggah mandiri skripsinya ke basis data Perpustakaan IPB. Kata kunci yang dibuat oleh mahasiswa tersebut kemudian diseleksi dan divalidasi untuk mendapatkan kata kunci yang memiliki makna lengkap yaitu membuang kata kunci yang salah dan kata kunci yang tidak memiliki arti secara utuh. Kemudian kata kunci tersebut diterjemahkan ke dalam bahasa Indonesia sebelum dioleh menggunakan VosViewer.

\section{HASIL DAN PEMBAHASAN}

\section{Gambaran umum penelitian mahasiswa FEM IPB}

Kajian ini mengidentifikasi skripsi Fakultas Ekonomi dan Manajemen, pembagian kelompok skripsi yang merupakan hasil penelitian mahasiswa strata 1 (S1) berdasarkan 5 (lima) departemen berikut: (1) Manajemen (2) Ilmu Ekonomi (3) Agribisnis (4) Ekonomi Sumber Daya Lingkungan (5) Ekonomi Syariah. Sebaran Jumlah hasil penelitian mahasiswa (skripsi) dari ke 5 bidang utama tersebut digambarkan oleh gambar 1 berikut : 


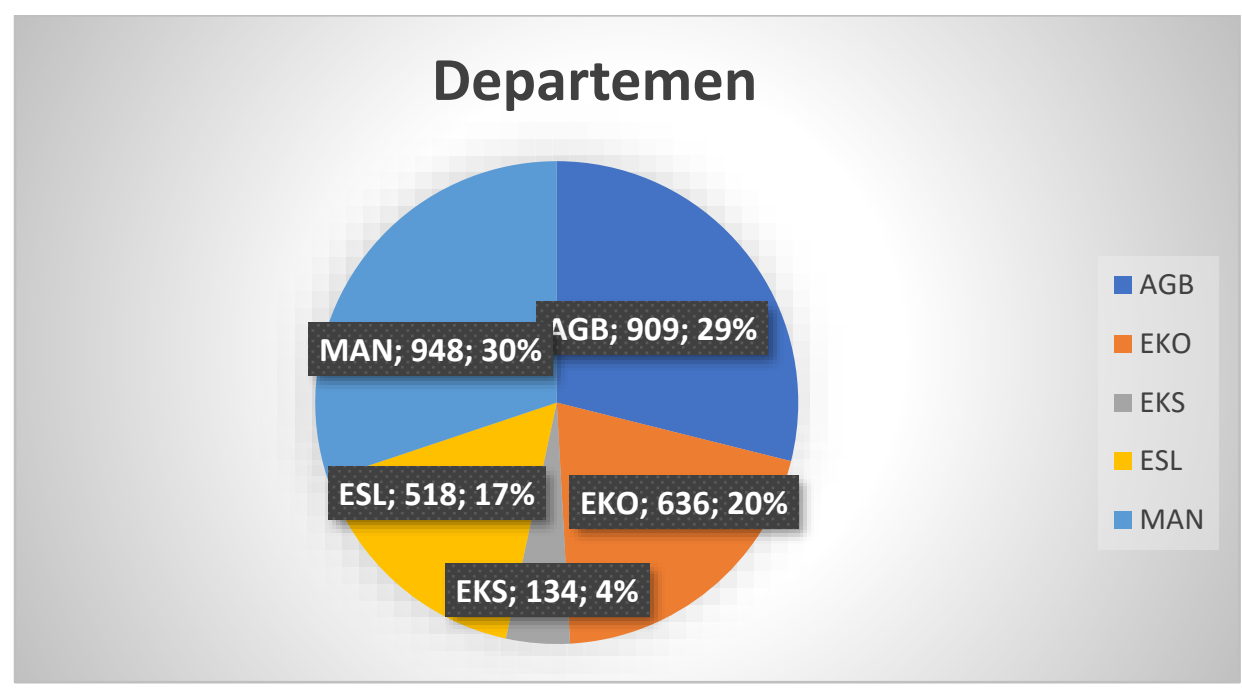

Berdasarkan gambar di atas, jumlah sebaran penelitian departemen di Fakultas Ekonomi dan Manajemen IPB dalam kurun waktu 2015 - 2019 yaitu sebanyak 3.145 penelitian. Sebaran penelitian tidak merata pada 5 departemen, yaitu Departemen Agribisnis dengan jumlah 909 judul penelitian (29\%), Departemen Manajemen dengan jumlah 948 judul penelitian (30\%) yang juga merupakan fakultas dengan judul penelitian terbanyak, Departemen Ekonomi dengan jumlah 636 judul penelitian (20\%), Departemen Ekonomi Sumber Daya Lingkungan dengan jumlah 518 judul penelitian $(17 \%)$, dan Departemen Ekonomi Syariah dengan jumlah 134 judul penelitian (4\%).

Rincian sebaran penelitian dari 5 departemen di Fakultas Ekonomi dan Manajemen IPB pada tahu 2015-2019 dapat dilihat pada table berikut.

Tabel 1 Sebaran skripsi menurut departemen pada Fakultas Ekonomi dan Manajemen IPB lulusan tahun 2015-2019

\begin{tabular}{rlrrrrrr}
\hline \multirow{2}{*}{ No. } & \multirow{2}{*}{ Dept } & \multicolumn{7}{c}{ Tahun } & \multirow{2}{*}{ Jumlah } \\
\cline { 3 - 7 } & & $\mathbf{2 0 1 5}$ & $\mathbf{2 0 1 6}$ & $\mathbf{2 0 1 7}$ & $\mathbf{2 0 1 8}$ & $\mathbf{2 0 1 9}$ & \\
\hline 1 & AGB & 163 & 220 & 208 & 189 & 129 & 909 \\
2 & EKO & 156 & 165 & 160 & 89 & 66 & 636 \\
3 & EKS & & & & 62 & 72 & 134 \\
4 & ESL & 115 & 88 & 102 & 112 & 101 & 518 \\
5 & MAN & 196 & 187 & 212 & 238 & 115 & 948 \\
\hline & Jumlah & 630 & 660 & 682 & 690 & 483 & 3145 \\
\hline
\end{tabular}

Jika sebaran penelitian dilihat berdasarkan tahun, penyebaran terlihat cukup merata dari tahun 2015-2018. Setiap departemen selama kurun waktu tahun 2015-2019 terdapat fluktuasi jumlah penelitian skripsi. Jumlah terbanyak adalah pada tahun 2018 dengan jumlah penelitian skripsi sebanyak 690 judul yang terdiri dari 189 judul skripsi Departemen AGB, 89 judul skripsi Departemen EKO, 62 judul skripsi Departemen EKS, 112 judul skripsi Departemen ESL dan yang tertinggi di 238 judul skripsi
Departemen MAN. Pada tahun 2019 penurunan jumlah penelitian skripsi yang signifikan dari tahun sebelumnya yaitu Departemen AGB (129), Departemen EKO (66), Departemen ESL (101) dan Departemen MAN sementara untuk Departemen EKS mengalami kenaikan jumlah penelitian dari tahun sebelumnya sebanyak 72 judul skripsi. Sebaran jumlah penelitian mahasiswa(skripsi) dari lima departemen tersebut digambarkan pada gambar 2 berikut. 


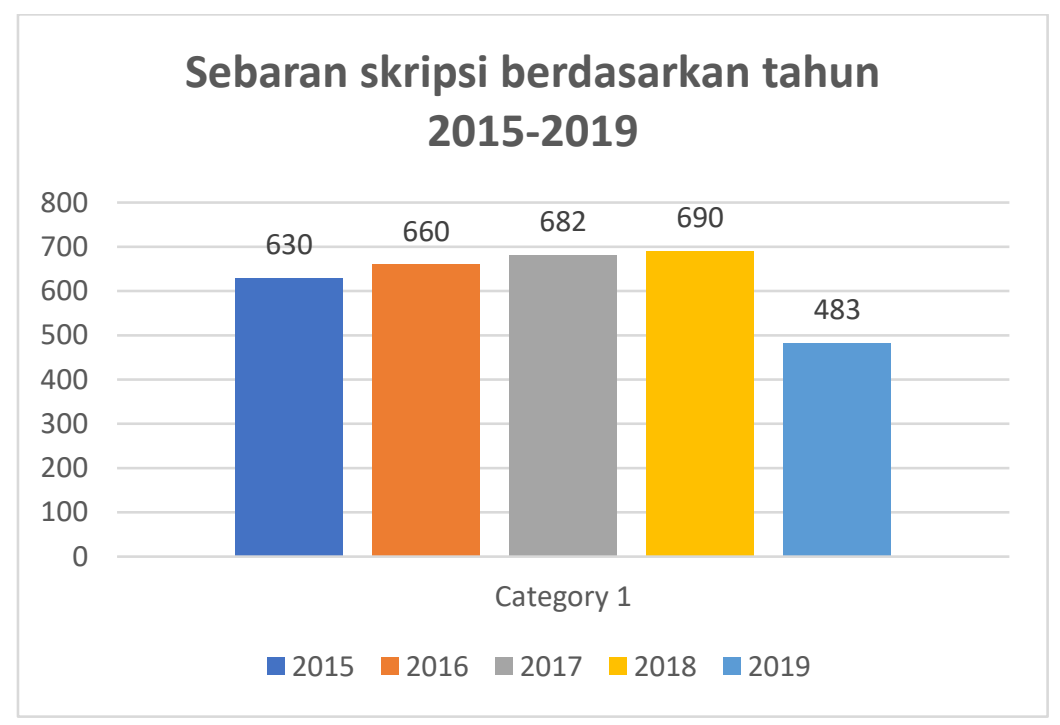

Gambar 1 Sebaran penelitian skripsi mahasiswa berdasarkan tahun 2015-2019

Berdasarkan gambar tersebut, dapat disimpulkan bahwa penyebaran penelitian merata pada tahun 2015-2018. Pada tahun 2019, terjadi penurunan jumlah penelitian yang dihasilkan oleh beberapa departemen, khususnya Manajemen yang menghasilkan 238 judul penelitian tahun 2018, hingga hanya menghasilkan 115 judul penelitian pada tahun 2019. Hal tersebut mempengaruhi penurunan jumlah penelitian keseluruhan dari tahun ke tahun.

Gambaran terkait penyebaran penelitian berdasarkan tahun dan departemen dapat dilihat pada gambar 3 berikut :

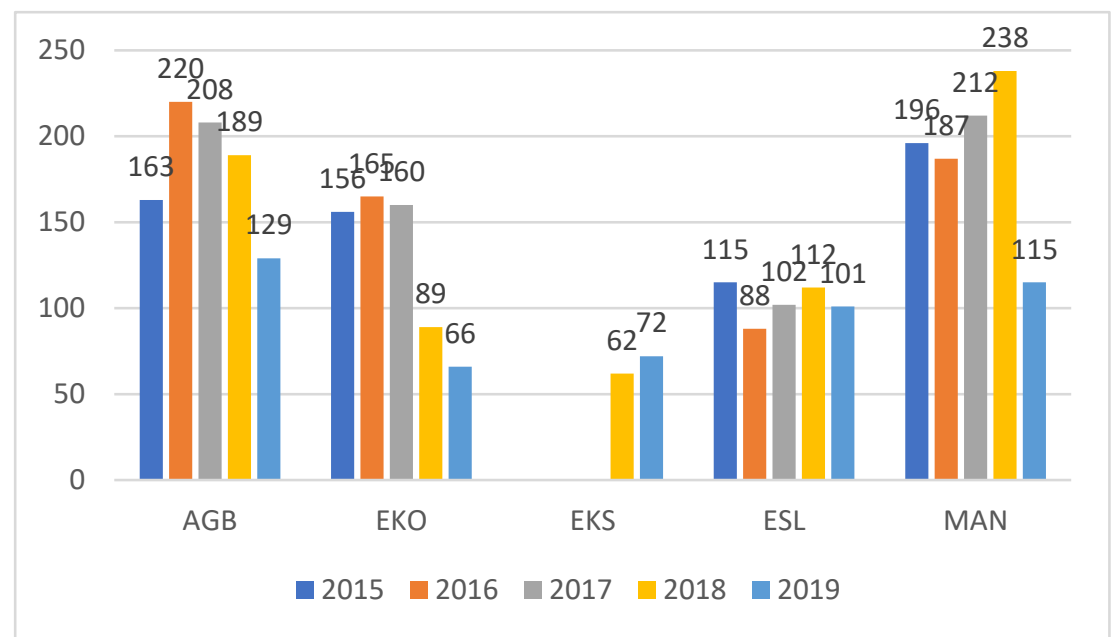

Gambar 2 Produktivitas departemen penghasil lulusan sarjana strata 1 kurun waktu 2014-2018 Fakultas Ekonomi dan Manajemen

Dari gambar diatas dapat terlihat bahwa pada 5 tahun terakhir (2019) satu-satunya departemen yang mengalami peningkatan hasil penelitian adalah Departemen Ekonomi Syariah (EKS). Departemen tersebut mengalami peningkatan dari jumlah 62 judul penelitian pada tahun 2018 menjadi 72 judul penelitian pada tahun 2019. Departemen Ekonomi Syariah termasuk departemen dengan jumlah hasil penelitian paling sedikit, kondisi tersebut dikarenakan Departemen Ekonomi Syariah merupakan departemen baru. Selain itu, Departemen Manajemen merupakan departemen dengan jumlah hasil penelitian terbanyak, yaitu 948 judul penelitian. Produktifitas penulisan penelitian terlihat meningkat pada tahun 2018 
dengan jumlah penelitian mencapai 238 judul dalam waktu 1 tahun.

Jika diurutkan berdasarkan jumlah judul penelitian yang dihasilkan, jumlah penelitian departemen terbanyak pertama, adalah Departemen Manajemen dengan jumlah penelitian 948 (30\%), penelitian terbanyak kedua, adalah Departemen Agribisnis dengan jumlah penelitian 909 (29\%), penelitian terbanyak ketiga, adalah Departemen Ilmu Ekonomi dengan jumlah $636(20 \%)$, penelitian terbanyak selanjutnya adalah Ekonomi Sumbar Daya Lingkungan dengan jumlah 518 (17\%) dan terakhir, penelitian dengan jumlah terkecil adalah Ekonomi Syariah dengan jumlah 134 (4\%).

\section{Peta bibliometrik kata kunci berdasarkan VosViewer}

Basis data skripsi lulusan Fakultas Ekonomi dan Manajemen IPB yang ada di
Perpustakaan IPB dilengkapi dengan kata kunci. Kata kunci tersebut sebagian dibuat sendiri oleh penulisnya, kemudian ditambahkan atau dilengkapi oleh pustakawan yang berasal dari Skema Klasifikasi UDC, di mana kata kunci seperti ini dalam ilmu perpustakaan disebut sebagai bahasa terkontrol atau "controlled language". Kegiatan analisis data dilakukan dengan bantuan Program VosViewer Versi 1.6.1.5 meliputi kegiatan analisis visualisasi jaringan (network visualization), visualisasi hamparan (overlay visualization), dan visualisasi kepadatan (density visualization). Jumlah kata kunci skripsi Fakultas Ekonomi dan Manajemen IPB tahun 2014-2019 sebanyak 4.700 kata kunci dengan peta sebaran jumlah kata kunci yang paling sering muncul (occurances) serta jumlah kekuatan keterhubungan (link) yang paling kuat (total link strength) dapat dilihat pada tabel 2 berikut.

Tabel 2. Lima Urutan Teratas Kemunculan Kata Kunci dan Kekuatan Keterhubungan (Link) Berdasarkan Hasil Analisis Vosviewer

\begin{tabular}{|c|l|l|l|}
\hline No & \multicolumn{1}{|c|}{ Keyword } & Occurance & \multicolumn{1}{c|}{ Total Link Strength } \\
\hline $\mathbf{1 1}$ & Pemasaran & 205 & 204 \\
\hline $\mathbf{2 2}$ & Sumber Daya Manusia & 156 & 156 \\
\hline 33 & Strategi Pemasaran & 146 & 145 \\
\hline 44 & Kualitas Produk & 141 & 140 \\
\hline 55 & Kualitas Layanan & 137 & 137 \\
\hline
\end{tabular}

Berdasarkan tabel diatas dapat diketahui jumlah lima urutan teratas kata kunci skripsi Fakultas Ekonomi dan Manajemen IPB tahun 2014-2019 berdasarkan jumlah kemunculan dan keterhubungan link yaitu: pertama adalah "pemasaran" dengan jumlah kemunculan terbanyak yaitu 205 kali dan kekuatan keterhubungan sebesar 204; kedua "sumberdaya manusia" sebanyak 156 kali dengan kekuatan keterhubungan sebesar 156; ketiga "strategi pemasaran" jumlah kemunculannya sebanyak 146 kali dan kekuatan keterhubungan sebesar 145; keempat "kualitas produk" dengan jumlah kemunculan sebanyak 141 kali dan kekuatan keterhubungan sebesar 140; dan yang kelima "kualitas layanan" dengan jumlah kemunculannya sebanyak 137 kali dan kekuatan keterhubungan sebesar 137.

\section{Visualisasi network peta kata kunci atau co-word}

Gambar dibawah ini merupakan perkembangan penelitian skripsi mahasiswa pada Fakultas Ekonomi dan Manajemen IPB tahun 2014-2019 berdasarkan hasil visualisasi network peta co-word. 


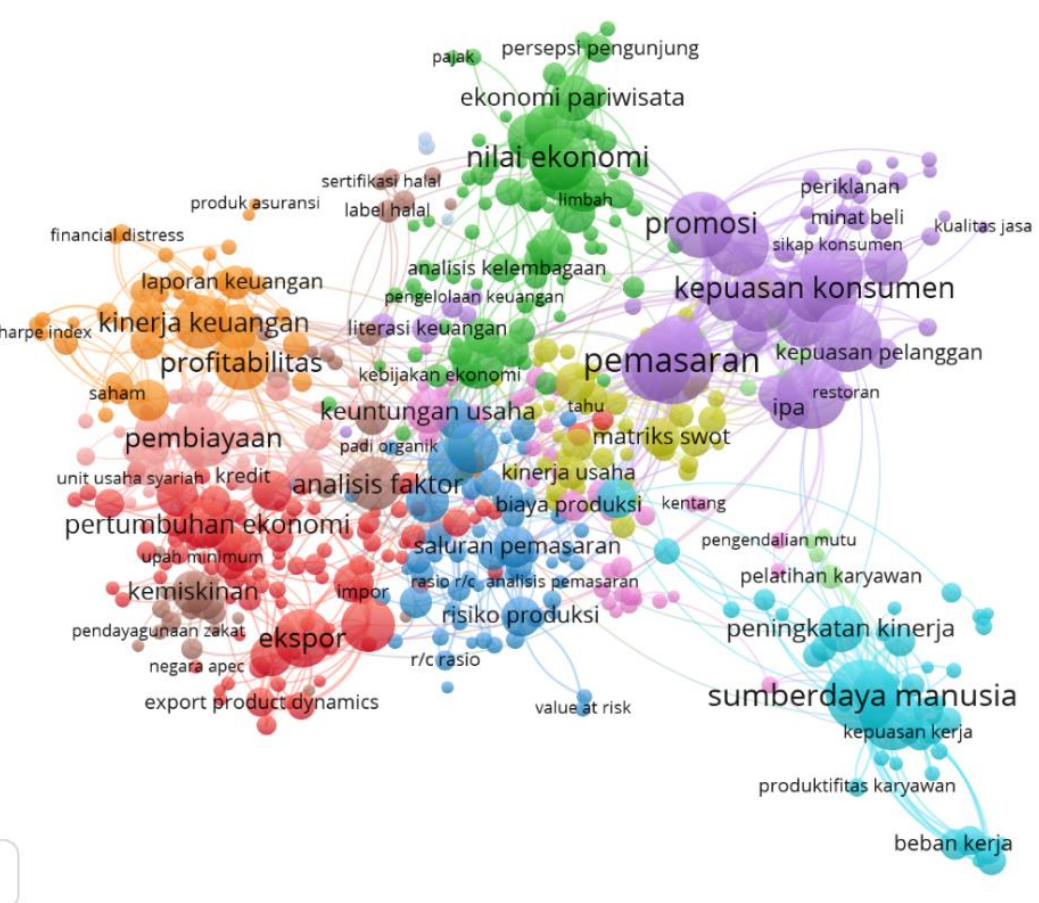

Gambar 4. Peta co-word dengan pada skripsi lulusan Fakultas Ekonomi dan Manajemen IPB tahun 2015-2019 dengan batasan kemunculan kata kunci sekurang-kurangnya 5 kali

Gambar di atas merupakan peta coword dengan batasan kemunculan kata kunci sekurang-kurangnya 5 kali yaitu sebanyak 567 items yang tersebar pada 12 kluster. Kluster terbesar yaitu kluster 1 terdiri dari 102 kata kunci dan kluster yang paling kecil yaitu kluster 12 terdiri dari 3kata kunci. Selain itu gambar tersebut juga memberikan informasi visualisasi jaringan kata kunci hasil analisis Program VosViewer Versi 1.6.1.5 dimana terdapat beberapa kluster kata kunci yang saling bertautan antara satu kata kunci dengan kata kunci lain. Gambar "bulatan" pada peta tersebut memperlihatkan jumlah kata kunci yang muncul, semakin besar ukuran "bulatan" tersebut, maka semakin banyak pula jumlah kata kunci yang ditemukan pada dokumen yang dianalisis. Demikian juga sebaliknya, semakin kecil ukuran "bulatan" tersebut, maka semakin sedikit jumlah kata kunci yang ditemukan pada dokumen yang dianalisis. Pada gambar di atas terlihat ukuran "bulatan" yang menggambarkan "pemasaran" adalah bulatan yang paling besar, hal ini menandakan bahwa kata kunci "pemasaran" merupakan jumlah yang terbanyak dibandingkan dengan kata kunci yang lain seperti "sumberdaya manusia", "strategi pemasaran" dan lain sebagainya. 


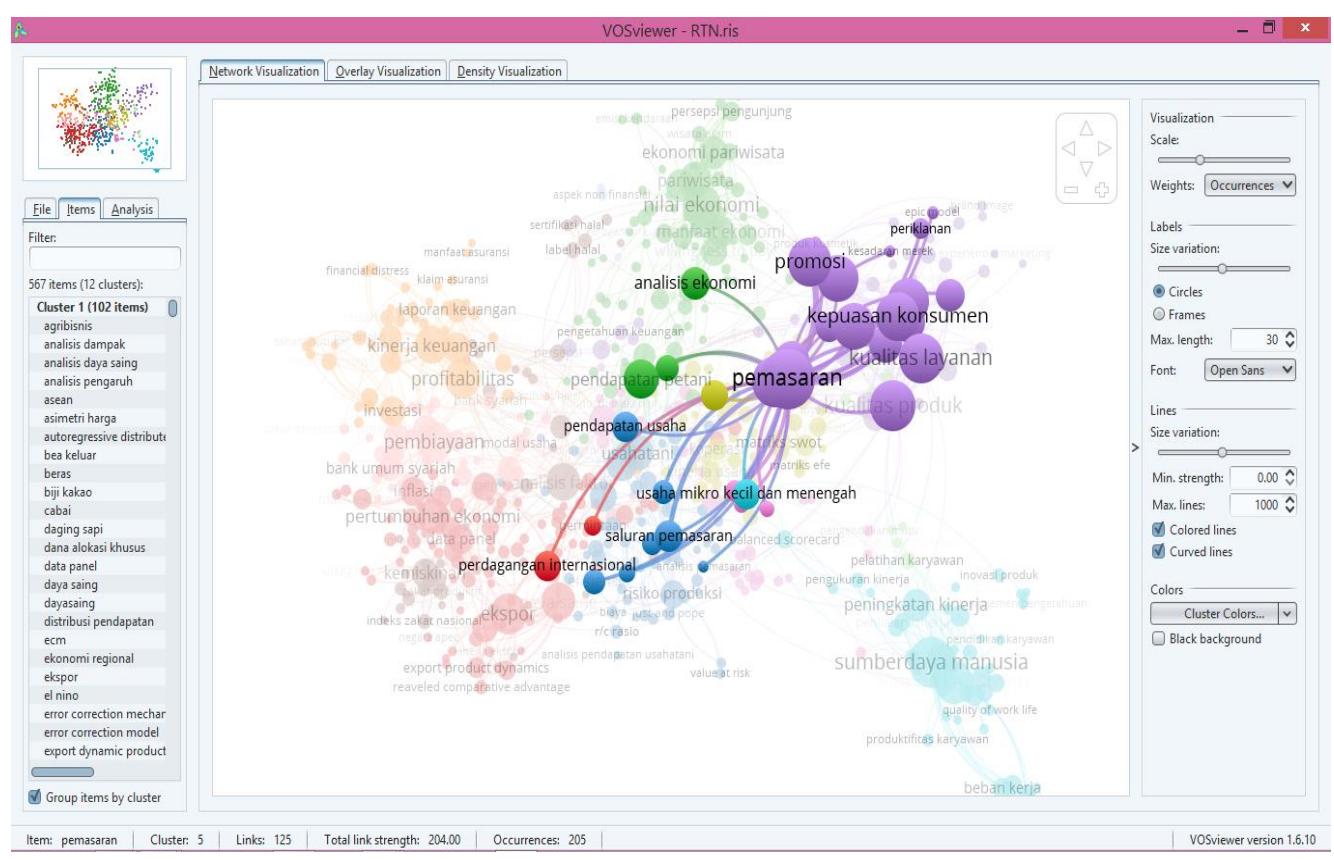

Gambar 5. Peta kluster pada kata kunci “pemasaran” yang terdapat dalam skripsi lulusan Fakultas Ekonomi dan Manajemen IPB tahun 2015-2019

Kata kunci "pemasaran" merupakan kata kunci yang muncul paling banyak dengan kekuatan keterhubungan (link) paling kuat.
Gambar 11 menampillkan peta untuk kata kunci "pemasaran". Sedangkan peta untuk kata kunci lainnya dapat dilihat pada gambar selanjutnya.

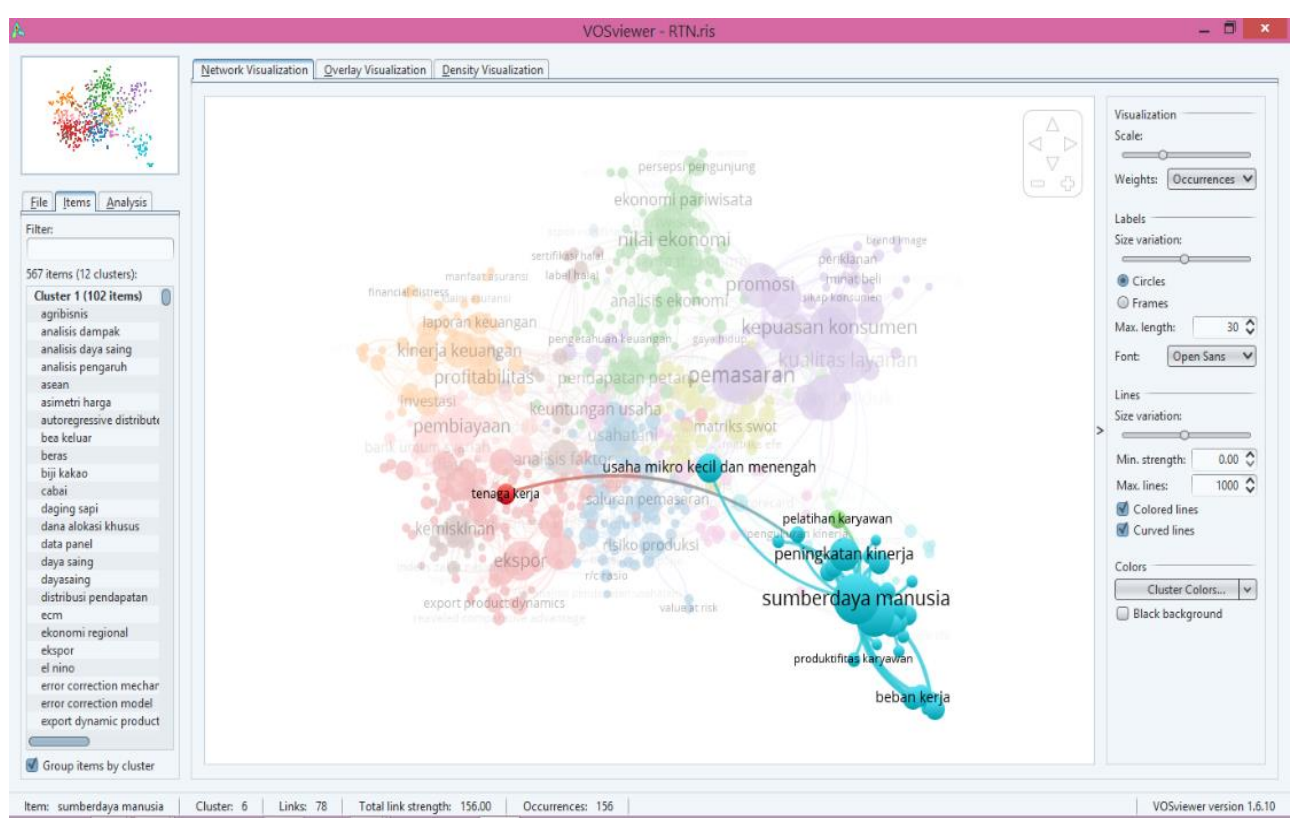

Gambar 6. Peta kluster pada kata kunci "sumberdaya manusia” yang terdapat dalam skripsi lulusan Fakultas Ekonomi dan Manajemen IPB tahun 2015-2019 


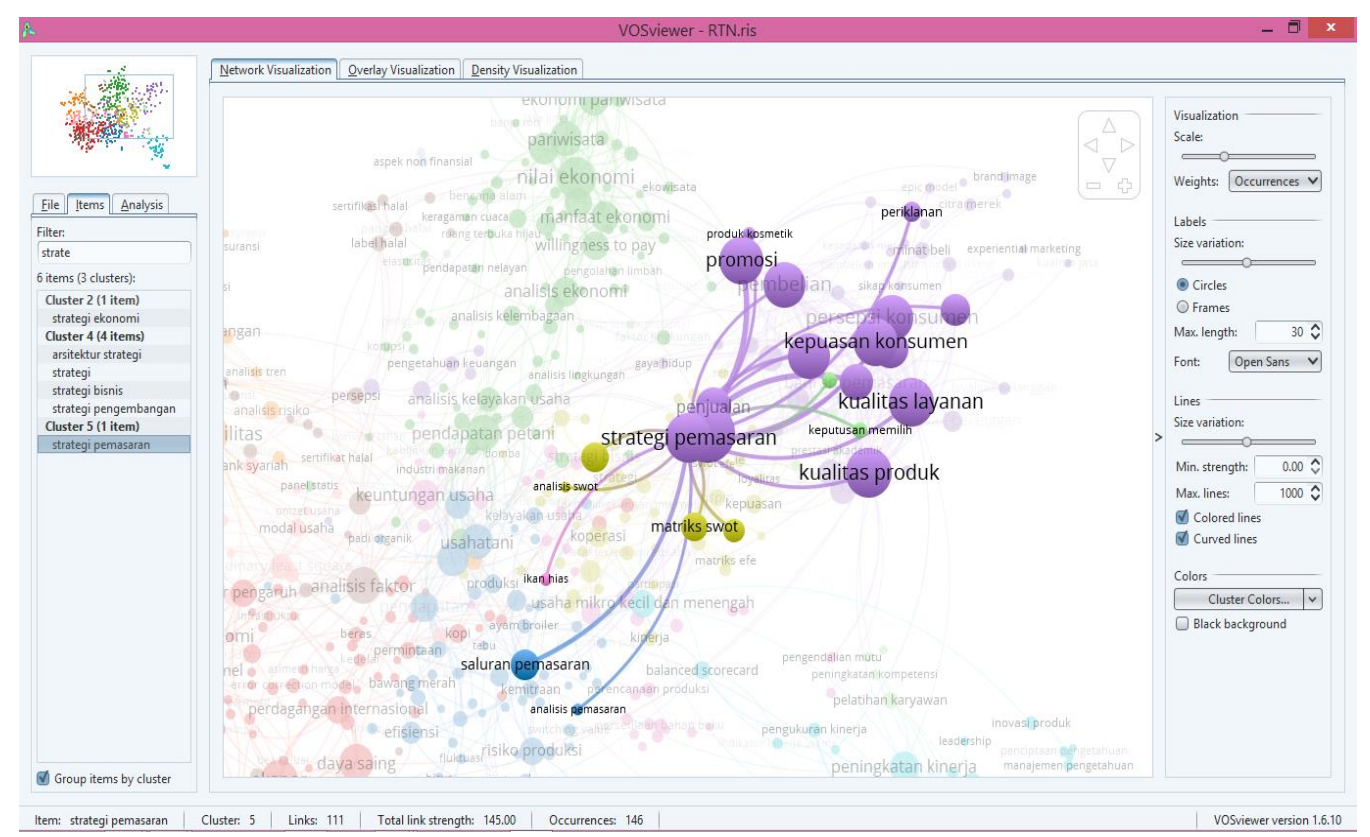

Gambar 7 Peta kluster pada kata kunci “strategi pemasaran” yang terdapat dalam skripsi lulusan Fakultas Ekonomi dan Manajemen IPB tahun 2015-2019

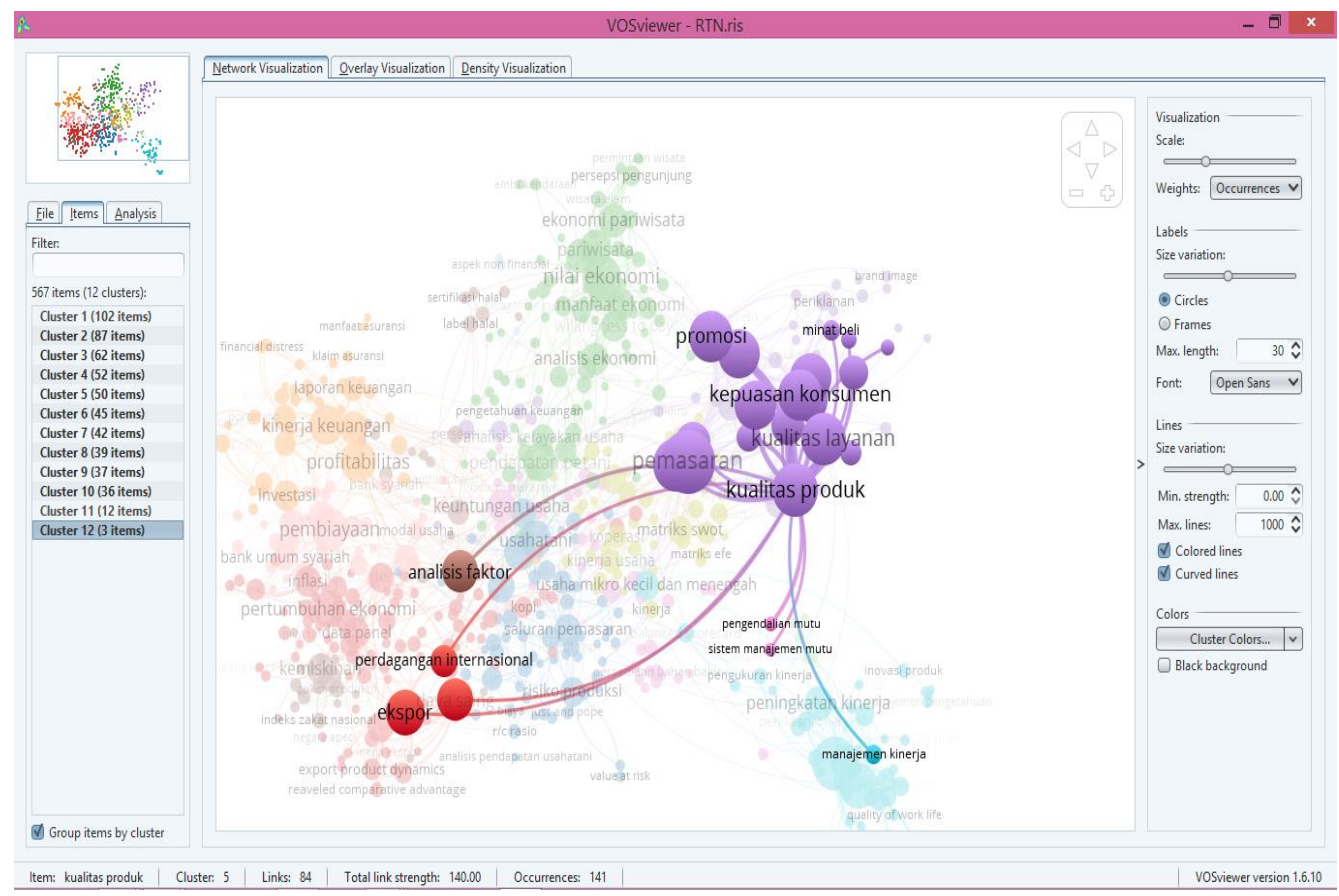

Gambar 8 Peta kluster pada kata kunci "kualitas produk" yang terdapat dalam skripsi lulusan Fakultas Ekonomi dan Manajemen IPB tahun 2015-2019 


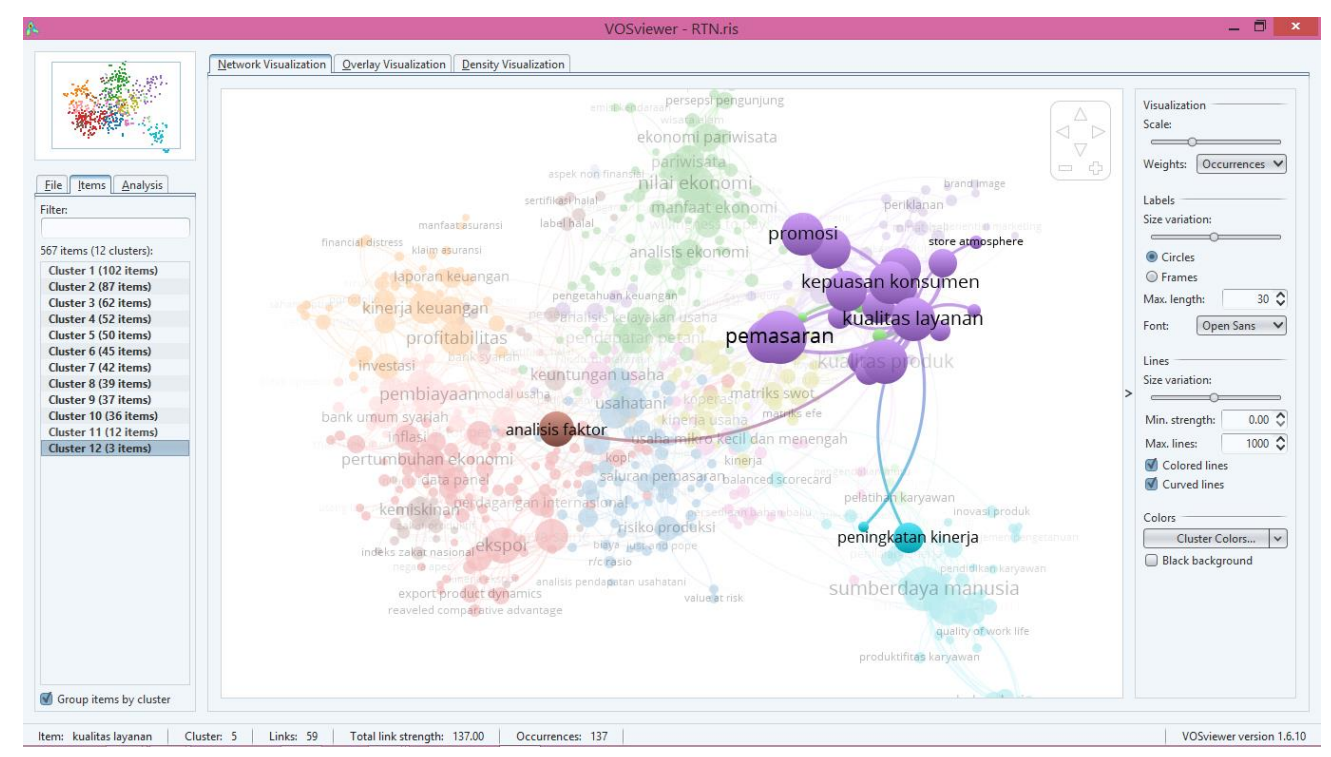

Gambar 9 Peta kluster pada kata kunci "kualitas layanan" yang terdapat dalam skripsi lulusan Fakultas Ekonomi dan Manajemen IPB tahun 2015-2019

\section{Visualisasi Density Peta Co-word}

Visualisasi densiti atau "density visualization" merupakan cara lain untuk melihat peta co-word atau peta kata kunci pada perkembangan penelitian dalam bidang ilmu tertentu.

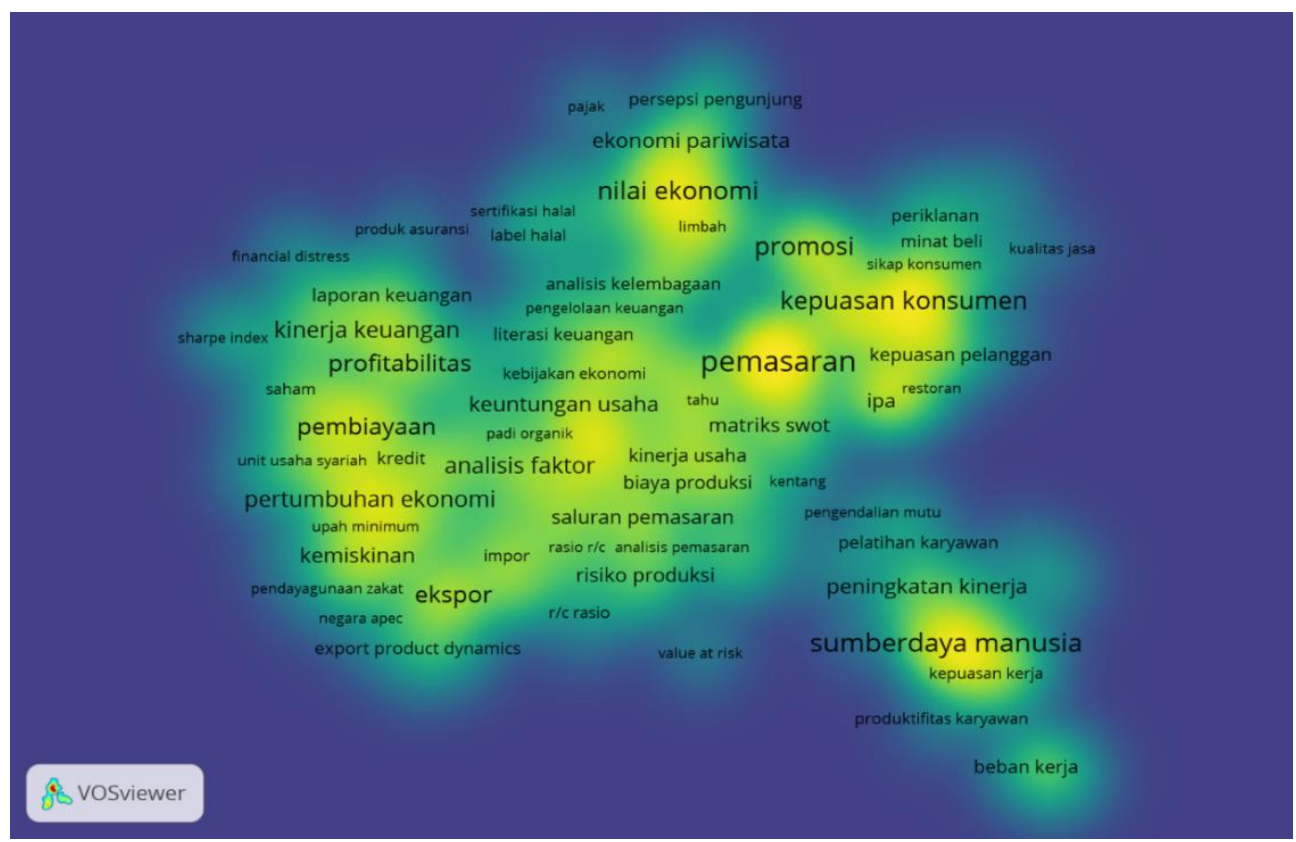

Gambar 10. Visualisasi densiti (density visualization) peta co-word pada penelitian mahasiswa Fakultas Ekonomi dan Manajemen IPB tahun 2015-2019

Pada peta visualisasi ini kepadatan kata kunci atau co-word diperlihatkan menggunakan warna. Semakin padat warna yang digambarkan pada peta, maka semakin padat volume atau jumlah kata kunci tersebut. Sebaliknya, semakin tipis warna yang ditampilkan, maka semakin kecil kepadatan kata kunci tersebut.
Melalui peta visualisasi densiti pada gambar tersebut kita dapat menyimpulkan bahwa penelitian terkait "pemasaran" merupakan topik penelitian terbanyak yang divisualisasikan dengan warna kuning yang paling pekat dibandingkan dengan topik-topik yang lain. 


\subsection{Produktivitas Dosen Pembimbing}

Dari hasil kajian diperoleh hasil bahwa dosen pembimbing paling produktif selama lima tahun terakhir atau periode 2015-2019 adalah
Munandardengan jumlah bimbingan utama sebanyak 126 mahasiswa bimbingan. Tabel 3 menunjukkan sepuluh dosen pembimbing paling produktif dalam membimbing skripsi mahasiswa.

Tabel 3. Sepuluh Dosen pembimbing paling produktif dalam membimbing skripsi mahasiswa, Fakultas Ekonomi dan Manajemen IPB selalam kurun waktu 2015-2019

\begin{tabular}{|l|l|c|c|c|}
\hline No & Nama Pembimbing & Bimbingan 1 & Bimbingan 2 & $\begin{array}{c}\text { Jumlah } \\
\text { Bimbingan }\end{array}$ \\
\hline 1 & Munandar, Jono Mintarto & 126 & 0 & 126 \\
\hline 2 & Dewi, Farida Ratna & 76 & 4 & 80 \\
\hline 3 & Sarma, Ma'mun & 65 & 6 & 71 \\
\hline 4 & Hubeis, Musa & 69 & 0 & 69 \\
\hline 5 & Najib, Mukhamad & 67 & 0 & 67 \\
\hline 6 & Purwanto, Budi & 66 & 0 & 66 \\
\hline 7 & Siregar, Edward Halomoan & 63 & 2 & 65 \\
\hline 8 & Kartika, Lindawati & 58 & 4 & 62 \\
\hline 9 & Sarianti, Tintin & 59 & 0 & 59 \\
\hline 10 & Cahyadi, Eko Ruddy & 54 & 3 & 57 \\
\hline
\end{tabular}

Posisi paling produktif kedua ditempati oleh Farida Ratna Dewi dengan jumlah bimbingan sebanyak 80 mahasiswa bimbingan yang terdiri dari76 bimbingan sebagai pembimbing utama dan 4 sebagai pembimbing anggota. Ma'mun Sarma menempati posisi ketiga dengan jumlah bimbingan 71 yang terdiri dari 65 bimbingan sebagai pembimbing utama dan 6 bimbingan sebagai pembimbing anggota. Jika di lihat dari data pembimbingan, skripsi mahasiswa strata 1 Fakultas Ekonomi dan Manajemen IPB mayoritas setiap mahasiswa di bimbing oleh satu pembimbing tanpa ada pembimbing anggota. Dari jumlah hasil penelitian selama kurun waktu 2015-2019, hanya 5 (lima) dosen yang menjadi dosen pembimbing anggota.

\section{KESIMPULAN}

Dari hasil kajian dapat ditarik beberapa kesimpulan sebagai berikut:

1. Jumlah penelitian skripsi mahasiswa Fakultas Ekonomi dan Manajemen IPB selama lima tahun terakhir (2015-2019) berjumlah 3145 judul penelitian. Jumlah tersebut terdiri atas skripsi mahasiswa Departemen IE sebanyak 636 judul penelitian (20\%), Departemen MAN sebanyak 948 judul penelitian (30\%), Departemen AGB sebanyak 909 judul penelitian (29\%), Departemen ESL sebanyak 518 judul penelitian $(17 \%)$ dan Departemen EKS sebanyak 134 judul penelitian (4\%).
2. Berdasarkan tahun kelulusan, jumlah skripsi terbanyak berada pada tahun 2018 yaitu sebanyak 690 judul, kemudian diikuti tahun 2017 sebanyak 682 judul, 2016 sebanyak 660 judul, tahun 2015 sebanyak 630 judul dan paling sedikit adalah pada tahun 2018 yaitu berjumlah 483 judul.

3. Penelitian mahasiswa Fakultas Ekonomi dan Manajemen IPB selama 2015-2019 meliputi empat kelompok utama UDC yaitu bidang "ilmu pengetahuan sosial" sebanyak 2503 penelitian, diikuti oleh "ilmu terapan" sebanyak 395 penelitian, dan kelompok "sains dan pengetahuan" sebanyak 247 penelitian.

4. Topik kajian paling banyak diteliti adalah "Situasi ekonomi, kebijakan ekonomi, manajemen ekonomi, perencanaan ekonomi. Produksi, jasa dan harga" dengan jumlah penelitian sebanyak 926 judul penelitian, sedangkan yang paling sedikit adalah topik terkait "Asuransi" dengan jumlah penelitian sebanak 6 judul penelitian.

5. Hasil penelitian mahasiswa strata 1 Fakultas Ekonomi dan Manajemen pada kurun waktu 5 tahun (2015-2019) yang tertinggi di Departemen Manajemen, bidang yang banyak di teliti adalah bidang keuangan, manajemen bisnis (206) judul penelitian, pasar/pemasaran (178) judul penelitian dan pembelian/pengadaan/manajemen stok (112) judul penelitian. Untuk bidang lainnya 
dapat dijadikan peluang untuk dijadikan bidang penelitian

6. 5 urutan teratas kata kunci berdasarkan jumlah kemunculan dan keterhubungan link yang pertama adalah "pemasaran" dengan jumlah kemunculan sebanyak 205 kali; kedua "sumberdaya manusia" sebanyak 156 kali; ketiga "strategi pemasaran" jumlah kemunculannya sebanyak 146 kali; keempat "kualitas produk" dengan jumlah kemunculan sebanyak 141 kali; dan yang kelima "kualitas layanan" dengan jumlah kemunculannya sebanyak 137 kali.

7. Keterhubungan (link) kata kunci yang paling kuat adalah "pemasaran" dengan total kekuatan keterhubungan sebesar 204 hubungan; kekuatan keterhubungan kata kunci "sumberdaya manusia" sebesar 156 hubungan; kekuatan keterhubungan kata kunci "strategi pemasaran"sebesar 145 hubungan; kekuatan keterhubungan kata kunci "kualitas produk" sebesar 140 hubungan; dan untuk kata kunci "kualitas layanan" sebesar 137 hubungan.

8. Menurut kata kunci pada analisis co-word menggunakan VosViewer penelitian mahasiswa Fakultas Ekonomi dan Manajemen IPB tahun 2015-2019 terbagi menjadi 16 kluster dengan kluster terbesar yaitu kluster 1 terdiri dari 69 kata kunci dan kluster yang paling kecil yaitu kluster 12 terdiri dari 3 kata kunci.

Dosen pembimbing utama paling produktif adalah Jono Mintarto Munandar dengan jumlah bimbingan sebanyak 126 orang mahasiswa

\section{Daftar Pustaka}

Concortium, U. (2019). UDC Master Reference File 12. Dipetik May 18, 2019, dari Universal Decimal Classification Concortium: http://www.udcc.org/

Darmono, \& Hasan, M. A. (2002). Menyelesaikan skripsi dalam satu semester. Jakarta: Grasindo.

Hidayat, A. (2012, 10 19). Penjelasan Analisis Deskriptif dan Tutorialnya Dengan Excel. Dipetik May 18, 2019, dari Statistikian: https://www.statistikian.com/2012/10/an alisis-deskriptif-dengan-excel.html

Institut Pertanian Bogor. (2017). Panduan program pendidikan sarjana. Bogor: IPB.

Kementrian Sekretariat Negara RI. (2019). UU No. 24 tahun 2019 tentang Ekonomi Kreatif. Jakarta: Sekretariat Negara.
Muljono, P., Sujana, J., \& Prabowo, B. (2009). Metodologi Penelitian dan Laporan Kearsipan. Jakarta: Penerbit Universitas Terbuka.

Paath, C. K. (2019, 11 13). Ini 5 Program Prioritas Nasional Bidang Perekonomian. Diambil kembali dari Berita Satu: https://www. beritasatu.com/ekonomi/585082/ini-5program-prioritas-nasional-bidangperekonomian

Purwoko. (2020). Mengenal fitur Vosviewer dan arti visualisasinya \#1. Diambil kembali dari grenengane pustakawan: http://www. purwo.co/2019/05/mengenal-fiturvosviewer-dan-arti.html

Rahayu, S., \& Saleh, A. (2017). Studi bibliometrik dan sebaran topik penelitian pada Jurnal Hayati terbitan 2012-2016. Pustakaloka, 9(2), 201-218. doi: https://doi.org/ 10.21154/pustakaloka.v9i2.1092

Ratnaningsih, \& Himawan, D. (2016). Peningkatan Layanan Data dan Informasi dalam rangka Memenubi Kebutuban Informasi di Perpustakaan Perguruan Tinggi (Suatu Kajian Deskriptif Analisis terhadap 5 Bunga Komersial Utama dan 7 Bunga Potensial Komersial). Dipetik May 18, 2019, dari IPB Scientific Repository: https:// repository.ipb.ac.id/handle/123456 $789 / 93672$

Ratnaningsih, R., \& Atnah, A. (2019). Pemetaan Bidang Ilmu Pada Skripsi Fakultas Ekologi Manusia Lulusan Tabun 2014-2018 Berdasarkan Standar Universal Decimal Classification . Bogor: Institut Pertanian Bogor.

Rencana Pembangunan Pemerintab Indonesia. (t.thn.). Diambil kembali dari Indonesia Investments: https://www.indonesiainvestments.com/id/proyek/rencanapembangunan-pemerintah/item 305

Romly, R. R. (2020, 02 27). Indonesia Belum Cocok Jadi Negara Maju, Ini Alasannya. Diambil kembali dari Kompas.com: kompas.com/read/2020/02/27/19191362 6/indonesia-belum-cocok-jadi-negaramaju-ini-alasannya

Saleh, A. R., \& Himawan, D. (2019). Pemetaan Informasi Sebaran Bidang Ilmu pada Penelitian Skripsi Fakultas Perikanan dan Ilmu Kelautan IPB Lulusan Tahun 20142018 Berdasarkan Standar Universal Decimal Classification. Visi Pustaka, 21(3), 227-240.

Sugiyono. (2014). Metode penelitian manajemen: Pendekatan kuantitatif, kualitatif, kombinasi, penelitian tindakan, penelitian evaluasi. Bandung: Alfabeta.

Tupan. (2016). Pemetaan bibliometrik dengan VosViewer terhadap perkembangan hasil penelitian bidang pertanian di Indonesia. Visi Pustaka, 18(3), 217-230.

Wikipedia. (2017, 11 27). Imu. Dipetik January 11, 2018, dari https://id.wikipedia. org/wiki/Ilmu 
